\title{
ENVIRONMENTAL DEGRADATION OF DURIAN SKIN NANOFIBRE BIOCOMPOSITE
}

\author{
Siti Nur E'zzati Mohd APANdi, HaZleen ANUAR* ANd \\ Siti Munirah Salimah Abdul Rashid \\ Department of Manufacturing and Materials Engineering, Faculty of Engineering, \\ International Islamic University Malaysia, P.O. Box 10, 50728 Kuala Lumpur, Malaysia \\ *Corresponding author: hazleen@iium.edu.my
}

(Received: 27th Feb 2018; Accepted: $9^{\text {th }}$ April 2018; Published on-line: $1^{\text {st }}$ June 2018)

https://doi.org/10.31436/iiumej.v19i1.903

\begin{abstract}
The effect of ultraviolet radiation on tensile properties, water absorption and optical properties of polypropylene (PP) reinforced with durian skin nanofibre (DSNF) composites was investigated. DSNF was obtained from fermentation of durian skin fibre using Rhizopus oryzae. X-ray diffraction (XRD) analysis and Sherrer equation were applied to measure the average particle size of DSNF which was determined as $51.2 \mathrm{~nm}$. PP and DSNF were melt-blended in a Haake internal mixer before compression moulded into composite specimens. The composites were exposed under ultraviolet (UV) radiation to simulate the effect of sunlight. The significant effect of maleic anhydride polypropylene (MAPP) was observed by the improvement recorded in tensile properties and reduction of water absorption in PP/DSNF composite. The colour index of composites increased with UV radiation exposure. Transmission electron microscope (TEM) images showed DSNF was well-dispersed in PP matrix in the presence of MAPP.
\end{abstract}

ABSTRAK: Kesan ultraungu (UV) terhadap sifat tegangan, penyerapan air dan sifat optik bagi polypropylene (PP) diperkuatkan dengan nanofiber kulit durian komposit telah disiasat. DSNF telah diperolehi daripada process penapaian fiber kulit durian menggunakan Rhizopus oryzae. Analisis difraksi sinar-x dan persamaan Sherrer telah digunakan untuk mengukur purata saiz zarah untuk DSNFyang telah diperolehi sebanyak $51.2 \mathrm{~nm}$. PP dan DSNF telah dicampur dalam pembancuh Haake sebelum mampatan dibentuk menjadi spesimen komposit. Komposit telah didedahkan di bawah radiasi ultraungu (UV) untuk mensimulasikan kesan cahaya matahari. Kesan yang penting terhadap polipropilena maleik (MAPP) telah diperhatikan dan setiap peningkatan dalam sifat tegangan dan pengurangan penyerapan air dalam komposit PP / DSNF telah direkod. Indeks warna komposit meningkat dengan pendedahan radiasi UV. Imej mikroskop elektron penghantaran (TEM) menunjukkan DSNF telah disebarkan dengan baik dalam matriks PP dengan kehadiran MAPP.

KEY WORDS: Durian skin nanofibre, ultraviolet radiation, MAPP, color index, water absorption, Rhizophus oryzae.

\section{INTRODUCTION}

Natural fibre reinforced composite for external application might experience exposure to harsh environments with high humidity. Biodegradable fibres are hydrophilic in nature and tend to attract water although in air (Ahmad et al. 2015). Celluloses present in the natural fibres are responsible for water uptake. In cellulosic cell wall fibre, the hydroxyl groups 
bond with water and hydrogen exhibit more tendencies to water. The higher volume fraction of fibre, the higher cellulose content, thus increase the moisture absorption. Moisture swells the fibres and break apart the fibres. The humidity absorbed by the composite without compromising decreased the mechanical and physical properties of the composite (Badia et al., 2014). Jana and Zhong (2007) reported that during ambient condition, fungal may be developed on surface of flax fibre when expose to hygrothermal condition for only 3 days. Therefore, the surface treatment is applied on biocomposite substance to overcome fungal growth. The chemical treatment using maleic anhydride polypropylene (MAPP) is one of methods to modify the hydrophilicity of natural fibre apart from strengthening the bonding between matrix and fibre (Joseph et al. 2002).

Food packaging is one of the main growing industry within plastic packaging market. Those of product packaging made from conventional plastic. Due to their durability and resistance to degradation tends to stay within landfill after been used (Yousif and Haddad, 2013). Recently, new research on food packaging industry essential for the composite materials developed to degrade under the exposure of ultraviolet. The polypropylene, polyethylene and polystyrene matrix are usually sensitive to ultraviolet rays. The plastic products will degrade their polymer chain via scission and destroyed the cross linking between polymeric molecules (Lopez et al. 2006). Exposure to ultraviolet radiation leading to reduction in mechanical properties of composite. Different type of radiations results in different kind of damage in products. Jana and Zhong (2007) revealed that composite used for outdoor application are exposed to UV radiation from sunlight and degraded the integrity of matrix. The degradation process by UV exposure are significance for food packaging application. Degradation of composite leads to significant change in its structure, usually characterized by a loss of its fragmentation properties and also reduction of its molecular weight when placed under UV environmental conditions. Several damaging effects on composite are dimensionless, surface erosion, and colour faded. Natural fibres however contributed to UV light absorption. Alternatively, to increase the lifespan of composite materials, coupling agent such as MAPP can be employed to alter the compatibility of composite constituent subsequently increase the durability of composite material.

The current work discussed the effect of UV radiation on the tensile properties, water absorption and optical properties of PP/DSNF composites. Different exposure times were studied to determine the degradation of composite. The influence of coupling agent in prolong the performances of PP/DSNF composite under ultraviolet radiation was also deliberated. Comparison was made with unexposed PP composite in terms of mechanical, physical and optical properties.

\section{EXPERIMENTAL METHOD}

Polypropylene grade 6331 was bought from Titan Pro Polymers (M) Sdn. Bhd. Maleic anhydride polypropylene was supplied by Sigma-Aldrich. Durian skin waste was collected from Pahang, Malaysia.

Preparation of DSNF started with chopped, ground and sieved of durian skin fibre (DSF) into 100-250 $\mu \mathrm{m}$ mesh-size. Then, durian skin nanofibre (DSNF) was produced through mechanical pre-treatment of DSF. The treatment process was continued with biological fermentation of Rhizopus oryzae. Rhizopus oryzae is a type of fungi that is naturally occurred from the expired bread and its strain with reference collection of American type culture collection (ATCC). It was sporulated and grown on potato dextrose agar (PDA). It was stored at $37^{\circ} \mathrm{C}$ for 3 days. The medium for fermentation was potato dextrose broth (PDB) which was prepared under controlled of $\mathrm{pH} 6$ and sterilized in an 
autoclaved at $121{ }^{\circ} \mathrm{C}$. The biological treatment started as Rhizopus oryzae grown on PDA collected by shaving using L-loop and extracting it with $25 \mathrm{~mL}$ sterilized distilled water. Size of the inoculum was $2-5 \times 105$ spore's $\mathrm{mL}-1$. The inoculums were then added into 250 $\mathrm{mL}$ Erlenmeyer flasks that contained $1 \mathrm{~g}$ DSF, $50 \mathrm{~mL}$ PDB and $50 \mathrm{~mL}$ deionized water. The biological fermentation process was conducted at $25{ }^{\circ} \mathrm{C}$ for 7 days with an agitation speed of $250 \mathrm{rpm}$ (Nur Aimi et al. 2011).

The structure and crystallinity of DSNF was determined using a Shimadzu X-ray diffractometer (XRD 6000) machine. The diffracted intensity of CuKa (wavelength of $0.1542 \mathrm{~nm}$ ) was recorded between $10^{\circ}$ and $35^{\circ}(2 \theta$ angle range) at $50 \mathrm{kV}$ and $40 \mathrm{~mA}$. The crystallinity index (CI) of the DSNF was calculated according to Scherrer equation as in Eq. (1).

$$
D=(0.9 \times 0.1541) \div(\beta \times \operatorname{Cos} \theta)
$$

$\mathrm{PP}$ and DSNF were mixed in Haake internal mixer at temperature $180{ }^{\circ} \mathrm{C}$ and $50 \mathrm{rpm}$ screw rotational speed. $3 \%$ of DSNF were added in compounding. The mixing process was carried out for $12 \mathrm{~min}$. For composite with coupling agent, $2.5 \mathrm{~g}$ MAPP was added and premixing was conducted before the ingredients were discharged into internal mixer. The composites were then compression moulded into specimens at $180{ }^{\circ} \mathrm{C}$ for $12 \mathrm{~min}$ for characterization purposes.

The samples of composite material were placed in the Xenon arc tester (Q-sun Xe1) according to ASTM D2565. The samples were then exposed under UV light radiation by using fluorescent lamp with wavelength of $420 \mathrm{~nm}(1.1 \mathrm{~W} / \mathrm{m} 2)$ at temperature $65^{\circ} \mathrm{C}$. This UV intensity offers spectrum which is similar to sunlight conditions during sunny day. The sunlight exposure provides different condition at different period of time due to different climate. However, the sunlight exposure limits the intensity with the existence of weather and humidity (Lopez 2006). Therefore, the UV radiation applied to samples was applicable to acquire accurate correlations with outdoors exposure. In this study, samples were exposed to 500,1000 and $2000 \mathrm{~h} \mathrm{UV}$ radiation. After UV radiation, all the composites specimens underwent tensile test, physical and optical analysis.

Tensile tests were conducted in according to ASTM D638 using a universal testing machine (LLOYD). The load cell was $10 \mathrm{kN}$ and the crosshead speed was $50 \mathrm{~mm} / \mathrm{min}$.

For water absorption test, PP/DSNF composites were immersed in water as per ASTM D570. The immersion took place until saturated data was obtained which was two months. The dimension and weight of the samples were recorded every day for the first 14 days and once a week afterwards.

The degradation of composite due to ultraviolet exposure was analyzed based on the colour index. The colour index measured by comparing the specimen before and after UV exposure. According to Ramos et al. (2014), colour value was evaluated in terms of $\mathrm{L}^{*}$ for $(0=$ black and $100=$ white $), a^{*}$ for $(-a=$ red or $+a=$ green $)$ and $b^{*}$ for $(-b=$ yellow or $+b=$ blue) index in CIE lab colour test. The colour index analyzed and compared using a Varian 50 CONC UV-visible spectrophotometer. The overall total colour difference index (E) which states the deviation from the reference stage was used as an indicator of degree of degradation. The colour index (E) is calculated as in Eq. (2).

$$
\Delta E=\left[(\Delta L *)^{2}+\left(\Delta a^{*}\right)^{2}+\left(\Delta b^{*}\right)^{2}\right]^{1 / 2}
$$

where, $\Delta \mathrm{L}=\mathrm{L}-$ Lref, $\Delta \mathrm{a}=\mathrm{a}-$ aref, $\Delta \mathrm{b}=\mathrm{b}$ - bref, $\mathrm{L}, \mathrm{a}, \mathrm{b}=$ colour accounted for the samples, Lref, aref, bref $=$ color coordinates of the control sample (DSNF/PP and DSNF/PP-MAPP before UV exposure). 
Morphological observation of tensile fracture specimen was conducted under field emission scanning electron microscope (FESEM) Jeol JSM-6700F. Transmission electron microscope (TEM) was used to observe the dispersion of DSNF in PP matrix. The sample were cut using ulra-microtome under glass transition temperature, $\mathrm{Tg}$. Then, it is mounted using cryogenic tool. The sample were prepared with dimension $0.5 \mathrm{~mm} \times 0.5 \mathrm{~mm}$ by cutting it used glass knife before placed inside the copper grid. In 12 hours, the sample were dip in osmium tetroxide. The CM 12 PHILIPS transmission electron microscope (TEM) (The Netherlands) with different magnification analysis was used to assess nano- to micro-scale dispersion.

\section{RESULTS AND DISCUSSION}

\subsection{Crystal Structure of DSNF}

The crystal structure of durian skin nanofibre (DSNF) was analyzed using X-ray diffractometer and X-ray diffractogram of DSNF is demonstrated in Fig. 1. The particle dimension was calculated using Scherrer equation in Eq. (1).

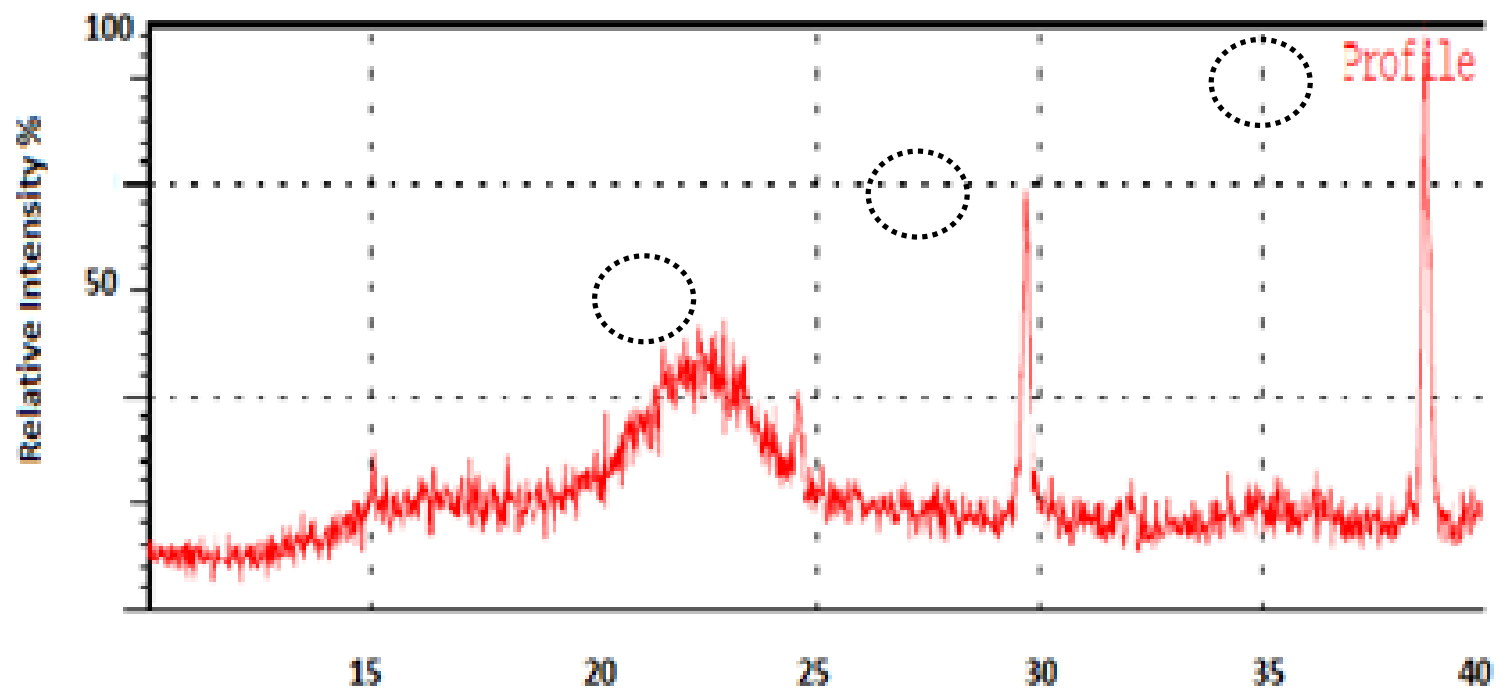

2-theta

Fig. 1: X-ray diffractogram of DSNF.

According to Fig. 1, the maximum peak of diffraction occurred at $22.4^{\circ}$. Another significant peak also appeared are at $35.1^{\circ}$ and $29.5^{\circ}$. Thus, the average diameter according to three maximum peak is $51.2 \mathrm{~nm}$. The end result indicates that the fibres were in nanometer range size. Roncero et al. (2005) reported that the intensity of crystalline peak is within $22^{\circ}$ and $23^{\circ}$ of $2 \theta$ angle, whereas for amorphous materials are between $18^{\circ}$ and $19^{\circ}$. The particle size of DSNF were calculated and tabulated in Table 1. The average diameter based on three maximum peak is $52 \mathrm{~nm}$. Table 1 shows the fibre diameter was reduced to nanometer scale. $1 \mathrm{~g}$ of DSF produced about $0.5 \mathrm{~g}$ of DSNF due to the removal of hemicellulose, lignin and pectin. 
Table 1: Diameter of durian skin nanofibre.

\begin{tabular}{lccc}
\hline & D1 & D2 & D3 \\
\hline 2-theta & $38.725^{\circ}$ & $29.7362^{\circ}$ & $22.36^{\circ}$ \\
& & & \\
\hline Diameter & $48.6 \mathrm{~nm}$ & $47.94 \mathrm{~nm}$ & $60.68 \mathrm{~nm}$ \\
\hline
\end{tabular}

\subsection{Effect of Ultra Violet Radiation on Tensile Properties of PP/DSNF Composites}

The tensile strength of PP/DSNF composites with and without MAPP under ultra violet (UV) radiation is shown in Fig. 2. It should be noted that the amount of DSNF in the PP matrix was $3 \mathrm{wt} \%$ based on optimum fibre content. From Fig. 2, composites without UV exposure showed the highest tensile strength, $27 \mathrm{MPa}$ (PP/DSNF) and $38 \mathrm{MPa}$ (PP/DSNFMAPP), respectively. Tensile strength for PP/DSNF-MAPP composite however dropped by almost $19 \%$ as UV radiation reached $2000 \mathrm{~h}$. The loss of tensile strength of PP/DSNF composites were due to degradation of fibres and matrix. The ultraviolet radiation absorbed by polymers alters the chemical structure, providing molecular chain scission as well as chain crosslinking (Azwa et al. 2013). UV radiation will lead to photodegradation due to photo-oxidation. Energy of exposure sunlight is adequate to cause the disruption of C-C bonds as a consequence of degradation (Yousif and Haddad, 2013). The high amorphous region in PP/DSNF composites from Table 2 further expedites the photo-oxidation process because of high permeability to oxygen (Beg et al. 2008).

It is noted in Fig. 2 that the tensile strength for both composites reduced with UV radiation. The presence of MAPP that function to bridge the PP and DSNF produced higher tensile strength than composite without MAPP. The presence of DSNF increased the oxidation rate, however good dispersion of fibre with compatibilizer decreased the oxidation rate (Matuana et al. 2011). Besides MAPP, DSNF in the form of nanofibre also imparted its strength thus enhanced the tensile properties of composite (Nur Aimi et al. 2014).

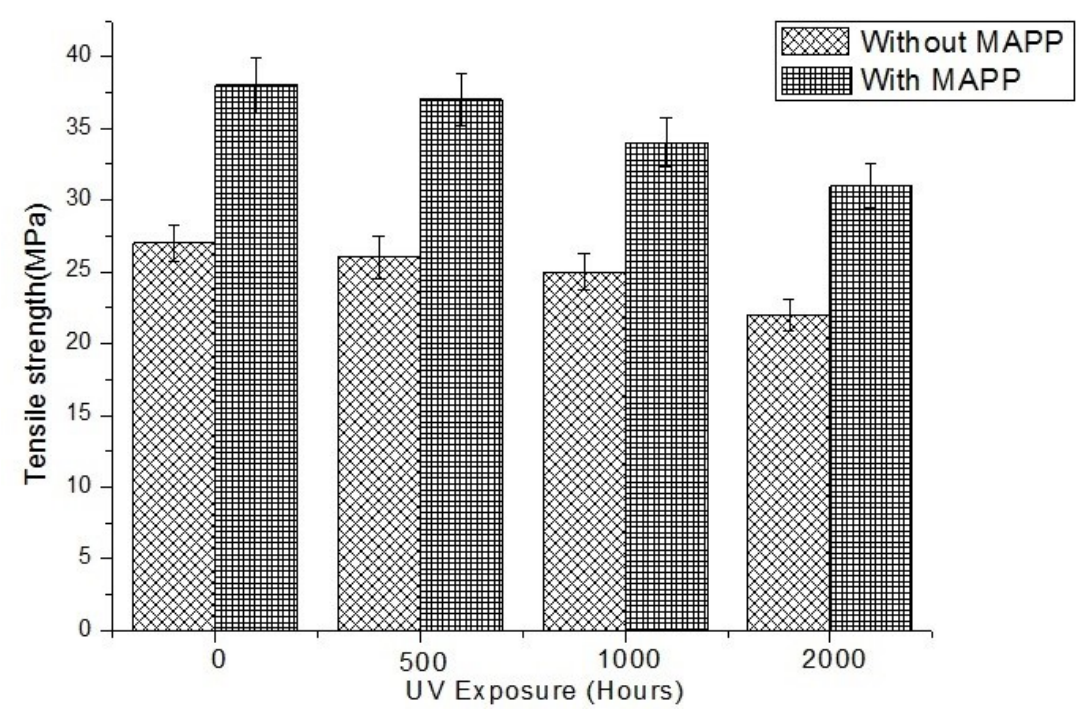

Fig. 2: The effect of DSNF content on tensile strength of PP/DSNF composites under UV radiation.

Table 2: Diffracted intensity and crystallinity of PP/DSNF composites. 


\begin{tabular}{cccc}
\hline & $\begin{array}{c}\text { Diffracted Intensity at } \\
\text { Amorphous Region (lam) }\end{array}$ & $\begin{array}{c}\text { Diffracted Intensity at } \\
\text { Crystalline Region (Irr) }\end{array}$ & $\begin{array}{c}\text { Percentage } \\
\text { Crystallinity (\%) }\end{array}$ \\
\hline PP/DSNF & 2.98 & 1.10 & 26.9 \\
\hline $\begin{array}{c}\text { PP/DSNF- } \\
\text { MAPP }\end{array}$ & 2.38 & 1.01 & 29.8 \\
\hline
\end{tabular}

The effect of UV exposure on the tensile modulus of polypropylene composites is shown in Fig. 3. In general, tensile modulus for PP composites are lower with UV exposure time. The trend was similar to tensile strength as seen in Fig. 2. Deterioration of polymer chain bonding in PP molecules downgraded the tensile modulus with time. In Fig. 4, the carbonyl groups detected at peaks 1732.38 and $1716.69 \mathrm{~cm}-1$ in FTIR spectrum are strongly believed to be one of the reasons that contributed to the absorption of $420 \mathrm{~nm}$ UV light and helped initiation of photochemical reactions (Matuana et al. 2011). In Fig. 4, there is a peak appeared at $2908 \mathrm{~cm}-1$ and $2921 \mathrm{~cm}-1$. This indicates the C-H stretching vibrations or known as carboxylic group. In Fig. 5, the carboxylic is seen in the region 2949.59, 2949.76, 2917.65 and $2917.71 \mathrm{~cm}-1$. Carboxylic groups were formed throughout the oxidative degradation of UV radiation (Munajat et al., 2018). During oxidation process, UV radiation generated carbon-oxygen bond react with oxygen-hydrogen single bond where cause increasing carboxylic functional groups. The reaction rate increased with number of broken polymer chains bonds in the exposure sample. Fig. 5 also illustrated the same peak at this region as in Fig. 4. As shown in Fig. 4 (b), one broad peak appeared in sample exposed under UV which related to O-H functional group located between range 3400 to $3200 \mathrm{~cm}^{-1}$. This peak appeared due to reaction $\mathrm{O}-\mathrm{H}$ bond with aging of oxidation process (Munajat et al., 2008). Meanwhile, this peak not invisible in Fig. 4(a). According to Bajwa et al. (2015), the peak presented in UV exposed specimens are typically related with existence of carboxylic group. This indicates that photodegradation occurred under UV light in PP composites.

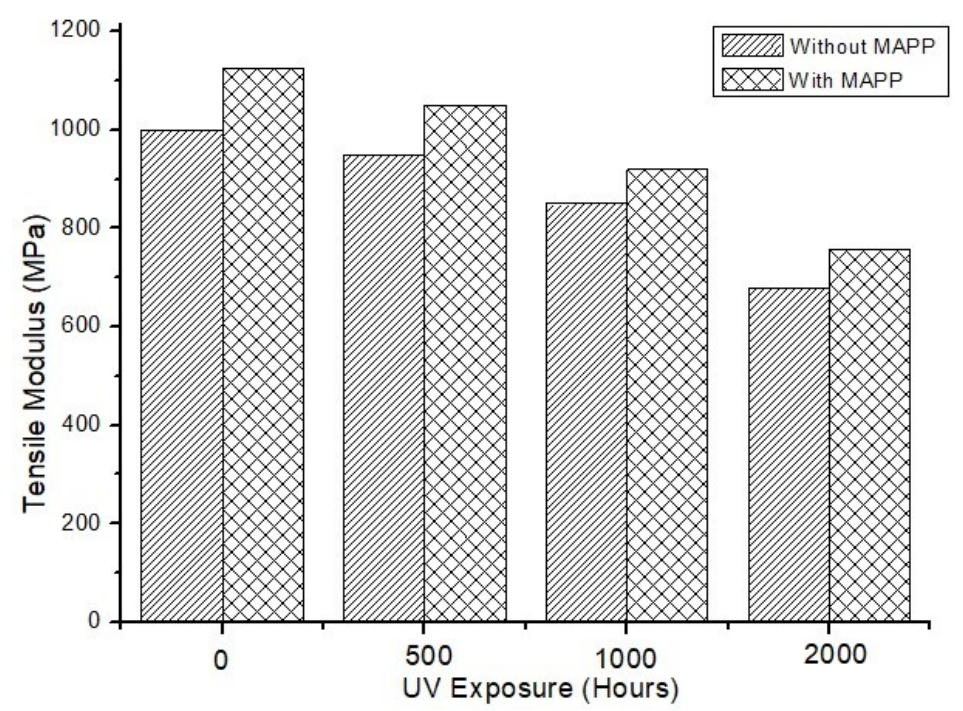

Fig. 3: The effect of DSNF content on tensile modulus of PP/DSNF composites under UV irradiation.

Aging or degradation of PP/DSNF composites are also attributed to lignin. DSNF composes of about 10\% lignin (Nur Aimi et al. 2015). Lignin absorb the UV radiation and 
photo yellowing mechanism occur in lignin (Beg et al. 2008). UV light encourages the production of radicals by oxidation. Radicals cause the chains of matrix to breakdown.

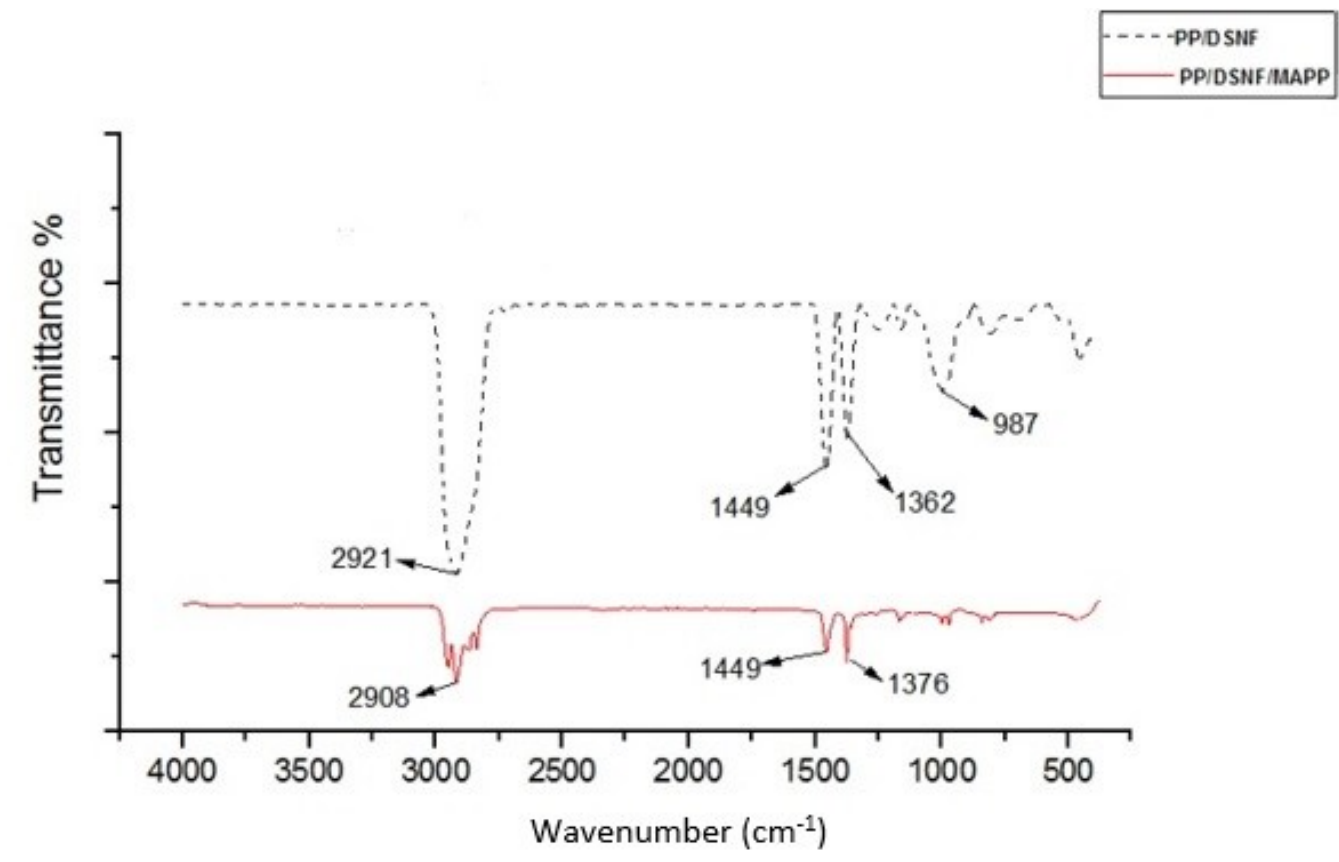

Fig. 4: FTIR of PP/DSNF composite before UV radiation.

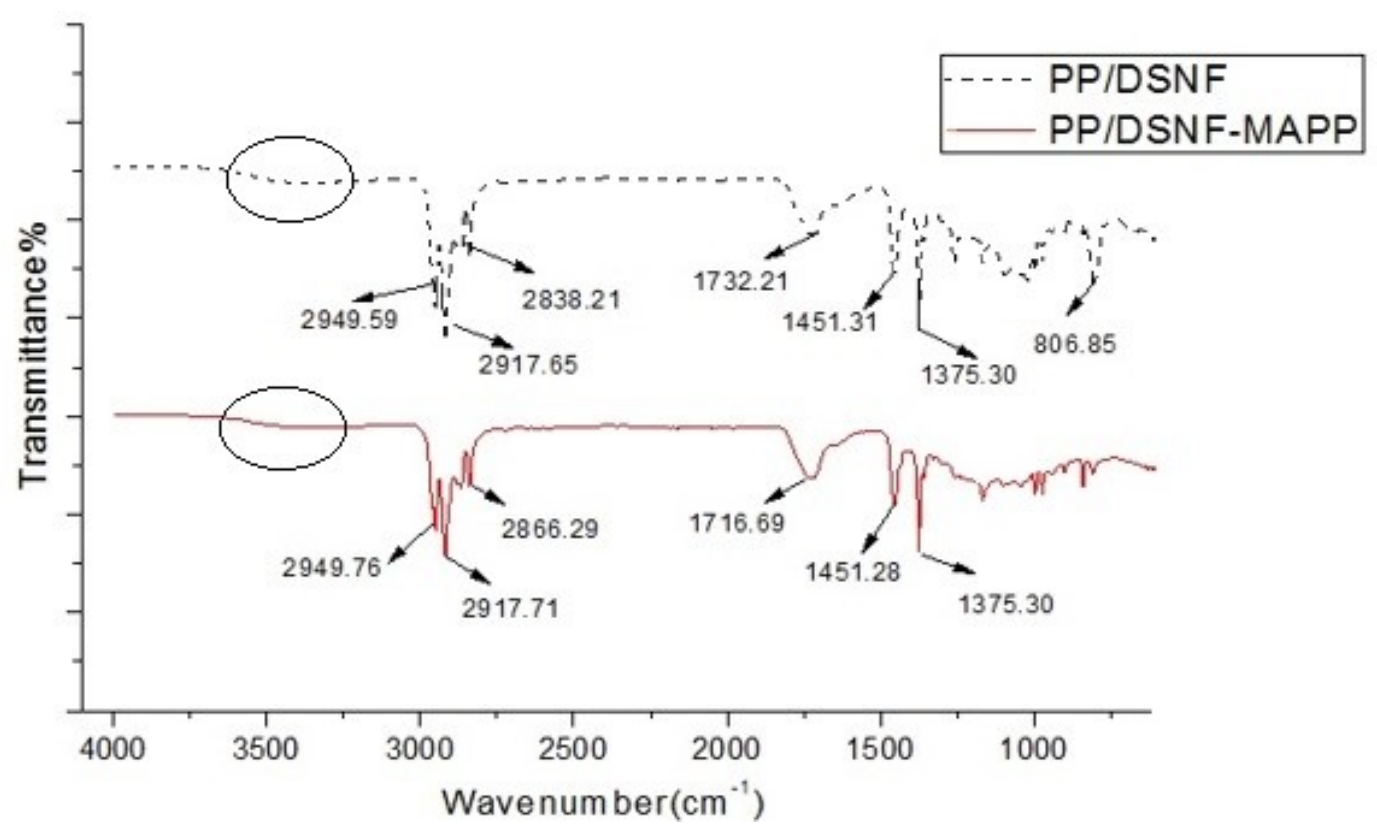

Fig. 5: FTIR of PP/DSNF composite after UV radiation.

Observation under FESEM in Figs. 6-7 revealed the debonding occurred possibly due to UV radiation which evidenced by the decrement both in tensile strength and tensile modulus of composites. In the absence of MAPP, fibres are easily pulled-out and debonding from the matrix. Fibre breakage is also noticed in Fig. 6. Void spaces between fibre pull-out 
and matrix is clearly seen in Fig. 6. The DSNF particle was weak attached to the PP matrix when load is applied it lead the fillers to be debond from the PP matrix and easily leaving behind evidences of voids. Manshor et al. (2014) mentioned in their analysis that the formation of void is appeared due to poor fiber orientation. Meanwhile, in Fig. 7 where the biocomposites with presence MAPP shows the DSNF were embedded in PP matrix. There is less traces of fiber pulled out due to strong interlocking bonding between fiber and matrix. However, the size of fiber tends to increase due to agglomeration and some error during produce DSNF. The nanofiber size already be proved in XRD test (Fig 1) and under TEM observation (Fig. 11). Therefore, further experiment required to improve this problem.

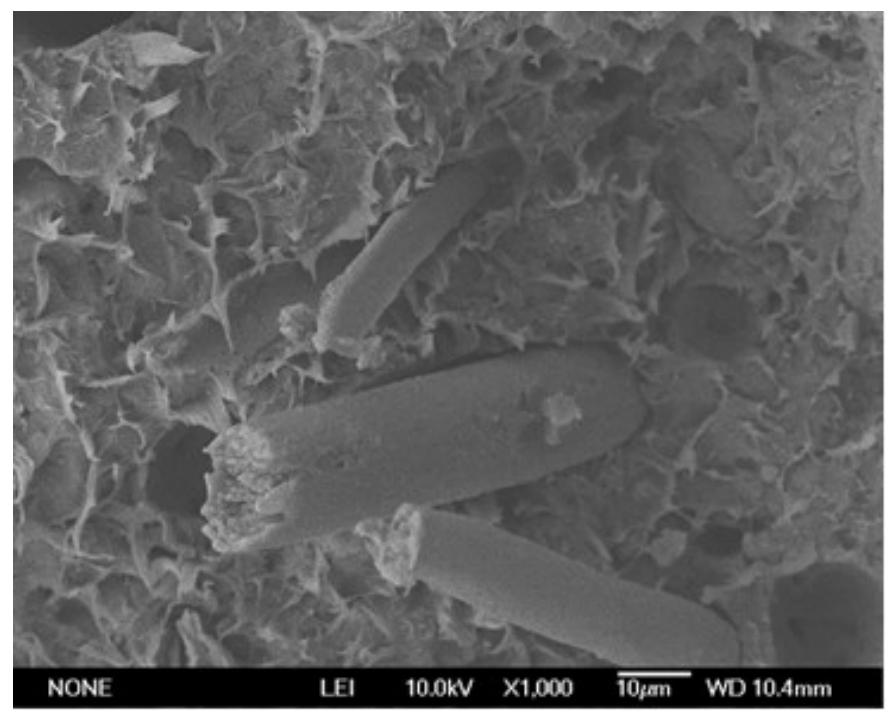

Fig. 6: FESEM micrograph of PP/DSNF composite after UV radiation.

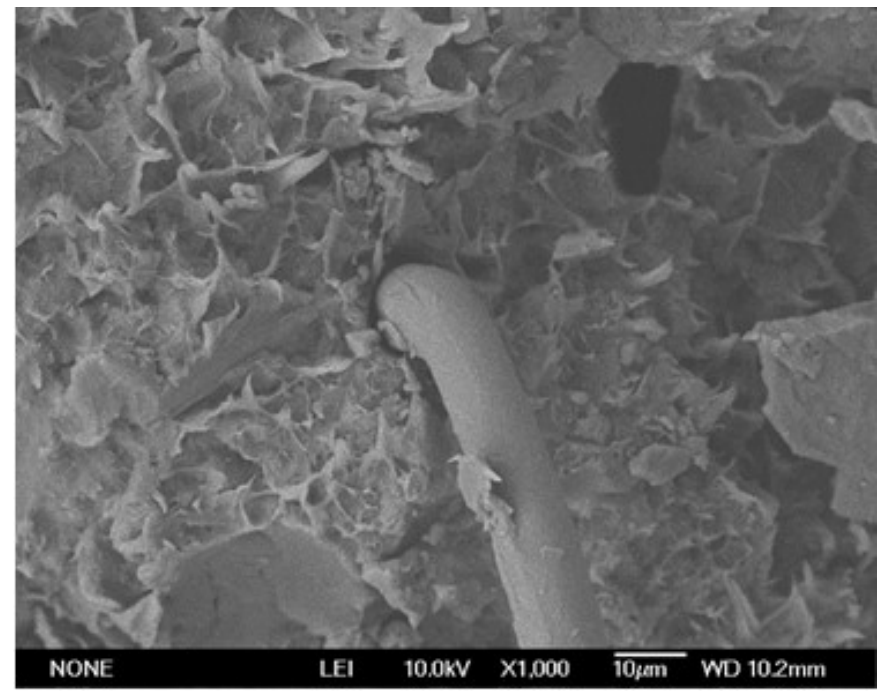

Fig. 7: FESEM micrograph of PP/DSNF-MAPP composite after UV radiation.

\subsection{Effect of Ultra Violet Radiation on Water Absorption of PP/DSNF Composites}

The effect of UV radiation on the water absorption of PP/DSNF composites are presented in Fig. 8. The water greatly affects the composite with regards to DSNF content in PP matrix from 0 to $5 \mathrm{wt} \%$. It was noted in Fig. 8, the first two weeks of immersion process demonstrated substantial water uptake by all the composites. Polypropylene matrix 
was the least absorbed water due to it hydrophobic characteristic. The water absorption test was conducted up to 70 days until saturated trend was obtained.

There were seven different compositions presented in Fig. 8. Sample without MAPP absorbed more water than the sample with coupling agent. Lack of wettability adhesion in composites resulted in poor interlocking between fibre and matrix (Joseph et al. 2002). In addition, water molecules are easily entrapped in gap of interfacial area leading to increasing of water absorption in fibre-matrix interphase. Composite with $5 \mathrm{wt} \%$ DSNF was dominated in water uptake with more than $5.74 \%$ water absorbed through 70 days. The amount of water uptake showed that the amount of fibre content influenced the behavior of composite material. Composites with $5 \mathrm{wt} \%$ DSNF absorbed the highest amount of water and vice versa. The fibres consist of cellulosic components giving rise to hydrophilic characteristic and thus tend to attract water. According to Patpen et al. (2015), natural fibre are exposed to water molecules in moisture condition. Therefore, the composite experienced swelling due to water absorption through voids spaces generated between fibre and matrix. Fig. 9 showed mechanism in biocomposites in the presence of water.

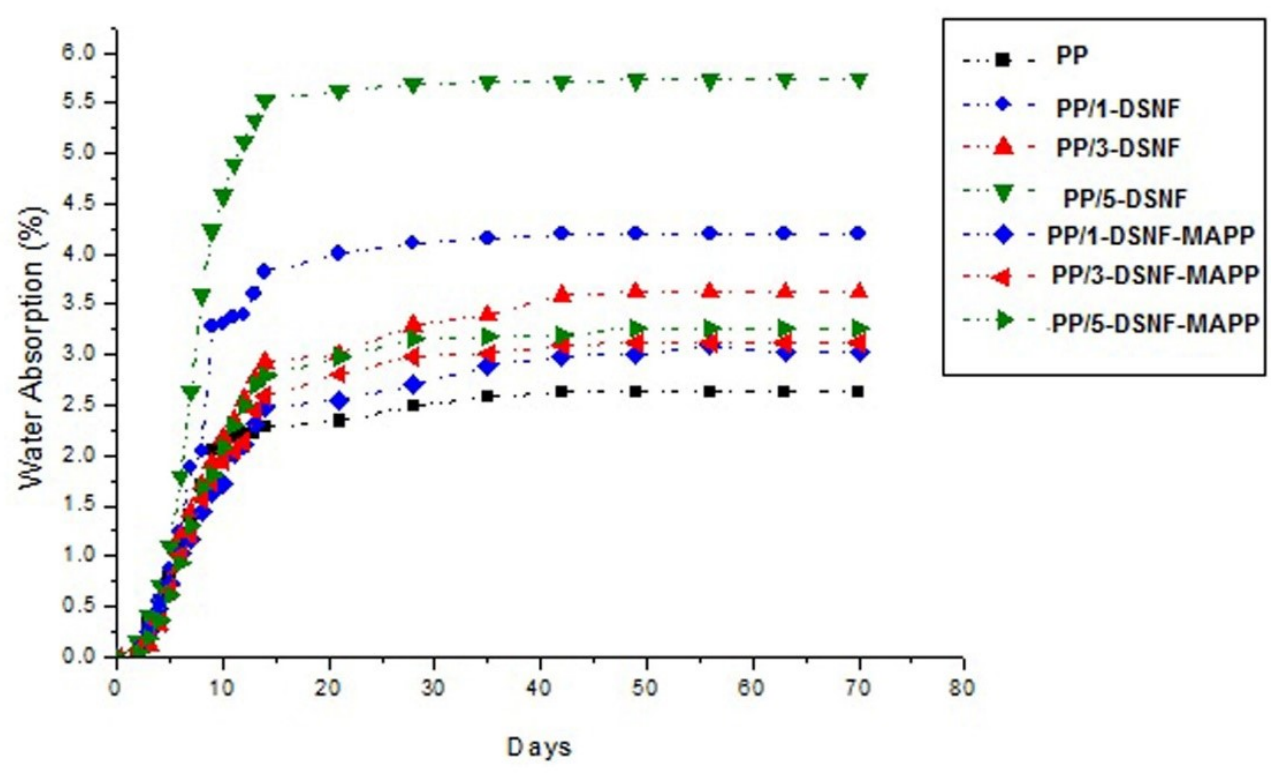

Fig. 8: The effect of DSNF content on water absorption of PP/DSNF composite under UV radiation.

Fig. 9 demonstrated the effectiveness of coupling agent where composite with MAPP able to stop the water absorbed into PP/DSNF composite as compared to composite without MAPP. Similar observation was reported by Badia et al. (2014) where the presence of MAPP reduced the water uptake into biocomposites. MAPP provides increase interfacial adhesion where less water accumulated in the interfacial voids and prevent water from entering DSNF. The effectiveness of MAPP decreased amount of water uptake by bamboo reinforced polymer which was reported by Thwe and Liao (2002). With the improvement as seen in Fig. 8, it is believed that MAPP induced less hydrophilicity in the PP/DSNF composite and promotes interfacial adhesion. 

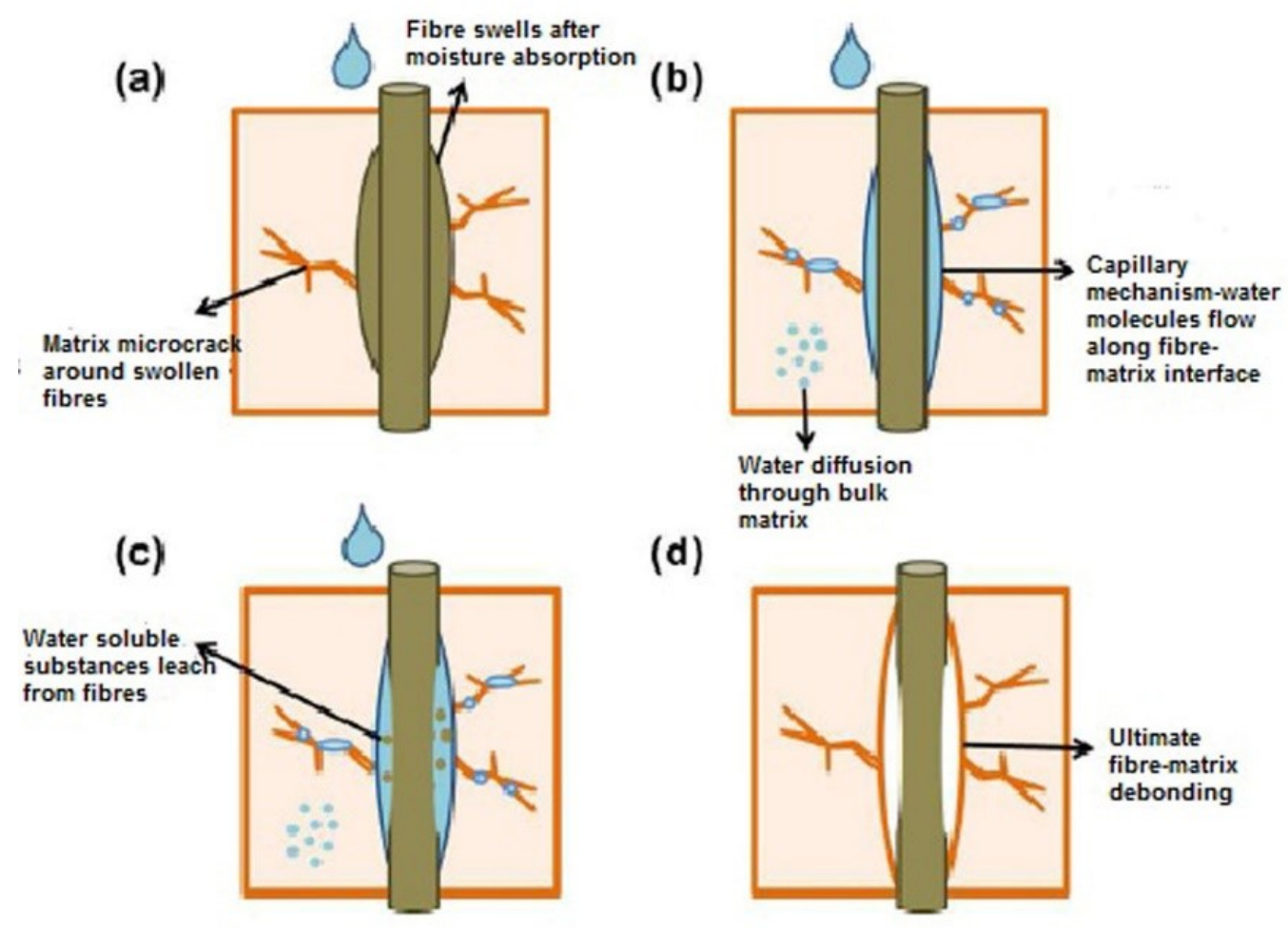

(d)

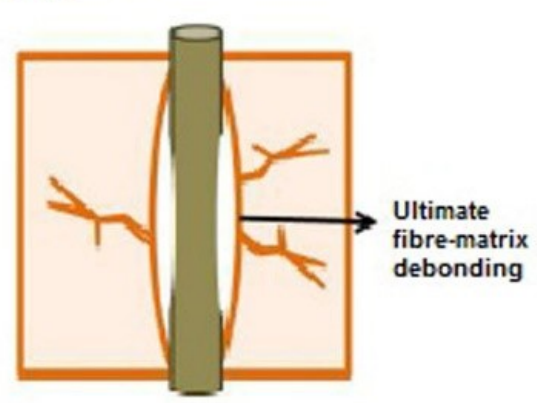

Fig. 9: The effect of water molecule on biocomposite (Faruk 2012).

\subsection{Effect of Ultra Violet Radiation on Optical Properties of PP/DSNF Composites}

The effect of UV radiation on optical properties of PP/DSNF composites are shown in Fig. 10. The optical properties investigated were compared for samples before and after UV exposure on composites with and without MAPP. The optical properties are given as Lvalue measured the effect of UV radiation on the physical appearance of PP/DSNF composites. The strength of colour were gained from the elements presence in the composites (Ramos et al. 2014)

Fig. 10 demonstrated the L-value for PP/DSNF composites at 0, 500, 1000 and 2000 hours of UV exposure. Sample with $2000 \mathrm{~h} \mathrm{UV}$ exposure showed the highest L-value as compared to other UV exposure time. The changes in colour lightness was due to photodegradation process via UV exposure time. Thermoplastic composites subjected to UV radiation may experience yellowish before photo-bleaching mechanism took place after $250 \mathrm{~h}$ exposure (Matuana et al. 2011). This showed that longer UV exposure time resulted in increased of colour index $(\Delta \mathrm{E})$ of PP/DSNF composites. According to Lopez et al. (2006), samples exposed longer under sunlight or outdoor would resulted in easy detect in terms of colour changes in the samples.

However, the presence of MAPP as coupling agent slightly changed the colour of PP/DSNF composite. Bajwa et al. (2015) also reported that discolouration of composite occurred due to UV radiation and oxidation of degraded polymer took place owing to chain scission between matrix and reinforcement. The presence of MAPP also protected the penetration of $\mathrm{UV}$ radiation in $\mathrm{PP} / \mathrm{DSNF}$ composite. 


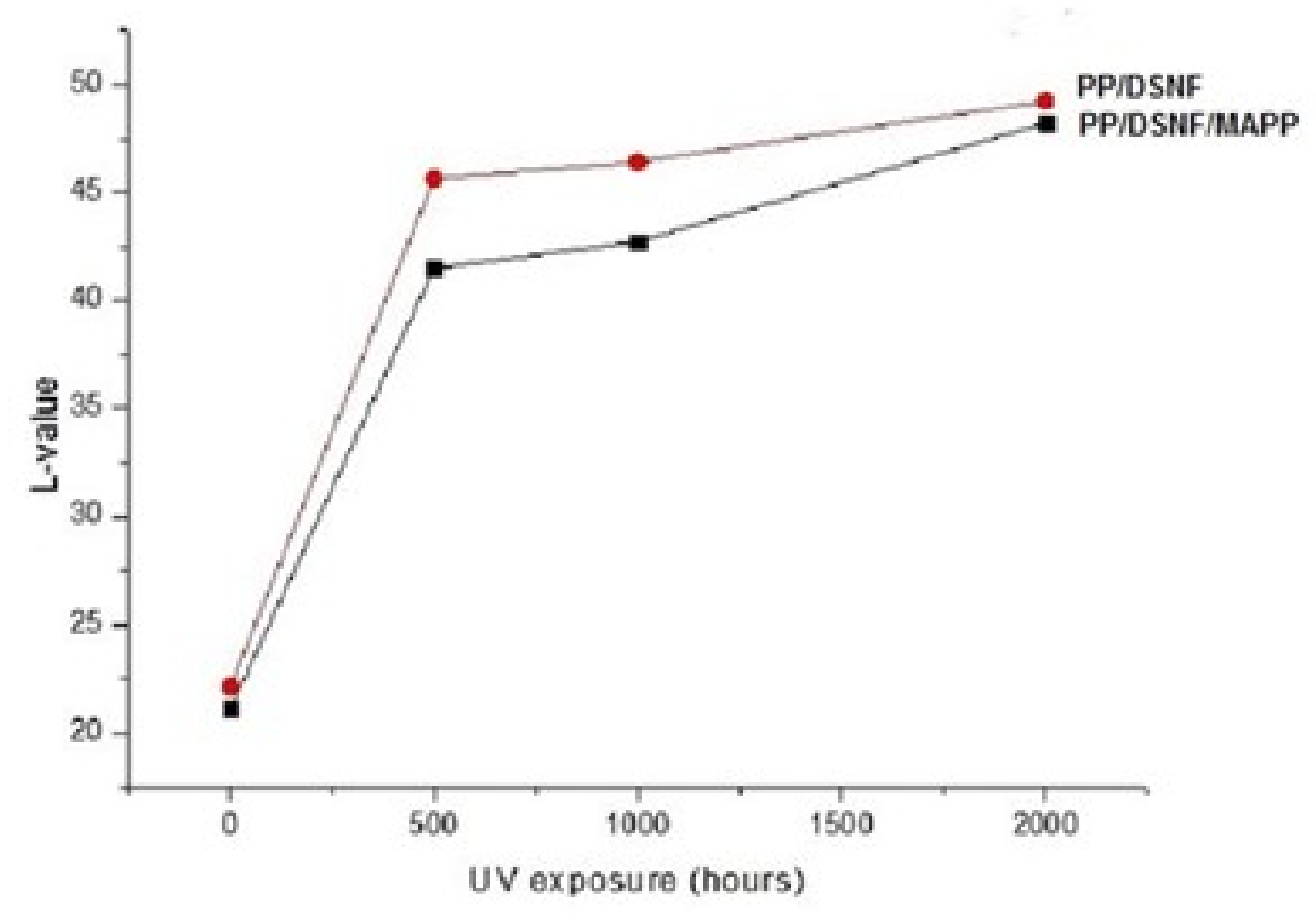

Fig. 10: The L-values of PP/DSNF composites.

\subsection{Transmission Electron Microscopy of PP/DSNF Composites}

The TEM images in Fig. 11 showed microstructure of PP/DSNF and PP/DSNFMAPP composites. Fig. 11(a) illustrated the image of a section of PP/DSNF without the presence of coupling agent where the black spots are the DSNF. From Fig. 10(a), the aggregations of DSNF are thicker and clearly evident which led to poor dispersion of nanofibre in PP composite. Fig. 2 also demonstrated weak tensile strength due to absent of coupling agent in PP composite. Similar finding was observed by Deng et al. (2010) on polypropylene and carbon nanotube. They reported poor adhesion occurred at the interface of polypropylene and carbon nanotube without the addition of coupling agent. Additionally, UV degraded the composite microstructure where there were different structures due to crack behavior occurred on the surface. Thus, the PP/DSNF composite as plastic packaging application can be decompose due to weathering condition.

Fig. 11(b) exhibited the images of PP/DSNF in the presence of MAPP coupling agent. Fig. 11(b) revealed that DSNF were well-dispersed. This indicated that the addition of MAPP improved the interaction between polypropylene and DSNF by reducing the agglomerations between them. Selvakumar et al. (2010) also reported that the tensile strength increased with addition of $5 \mathrm{wt} \%$ maleic anhydrides grafted polypropylene (MAHg-PP) where the reinforcement dispersed in PP/MMT nanocomposites. This finding confirmed the presence of coupling agent in composites led to increment of tensile properties as shown in Figs. 2-3. 

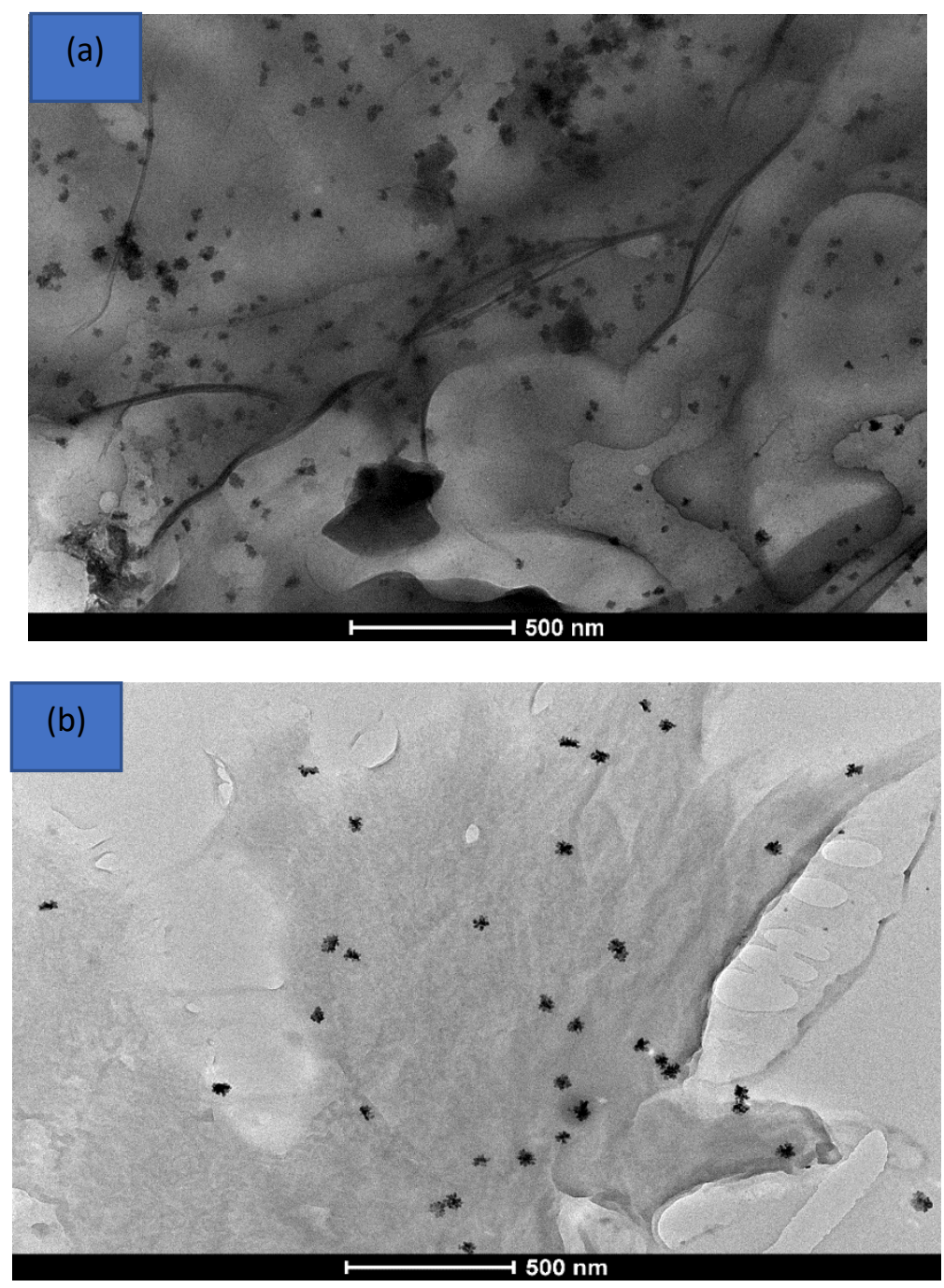

Fig. 11: Transmission electron microscopy (TEM) of (a) PP/DSNF and (b) PP/DSNFMAPP composite.

\section{CONCLUSION REMARKS}

As conclusion, durian skin nanofiber was successfully produced via fermentation using Rhizopus oryzae. The main targets of this project have been attained which also recommend that the application of durian skin nanofiber (DSNF) in biocomposites as reinforcement with MAPP can improves the mechanical properties of specimens. The environmental degradation under UV exposure significantly degraded the tensile and optical properties of PP/DSNF composites. The presence of MAPP however delayed the water absorbed by composites owing to good interaction of PP and DSNF. As food packaging application, UV exposure is one alternative ways to speed up the degradation process of materials. However, further experiment required to improve the result outcome.

\section{ACKNOWLEDGEMENT}

This work was financially supported by Fundamental Research Grant Scheme (FRGS16-003-0502) from Ministry of Education Malaysia. The authors would like to thank IIUM for research facilities in making this studies success. 


\section{REFERENCES}

[1] Ahmad F, Choi HS, Park MK. (2015) Natural Fiber Composites Selection in View of Mechanical, Light Weight and Economic Properties. A Review. Macromolecular Material Engineering, 300: 10-24.

[2] Azwa, ZN, Yousif BF, Manalo AC, Karunasena W. (2013) A review on the degradability of polymeric composites based on natural fibres. Material Destruction, 47: 424-442.

[3] Badia JD, Kittikorn T, Strömberg E, Santonja-Blasco L, Martínez-Felipe A, Ribes-Greus A, Ek M, Karlsson S. (2014) Water absorption and hydrothermal performance of PHBV/sisal biocomposites. Polymer Degradation Stability, 108: 166-174.

[4] Bajwa DS, Bajwa SG, Greg AH. (2015) Impact of biofiber and coupling agents on the weathering characteristics of composites. Polymer Degradation Stability, 120: 212-219.

[5] Beg MDH, Pickering KL. (2008) Accelerated weathering of unbleached and bleached kraft wood fibre reinforced polypropylene composites. Polymer Degradation Stability, 93: 19391946.

[6] Deng H, Bilotti E, Zhang R, Peijs T. (2010) Effective reinforcement of carbon nanotubes in polypropylene matrices. Journal Applied Polymer Science, 118: 30-41.

[7] Faruk O, Bledzki AK, Fink HP, Sain M. (2012) Biocomposites reinforced with natural fibers: 2000-2010. Progress Polymer Science,37: 1556-1596.

[8] Jana S, Zhong WH. (2007). FTIR study of ageing epoxy resin reinforced by reactive graphitic nanofibers. Journal Applied Polymer Science, 106: 3555-3563.

[9] Joseph PV, Rabello MS, Mattoso LHC, Joseph K, Thomas S. (2002) Environmental Effects on The Degradation Behaviour of Sisal Fibre Reinforced Polypropylene Composites. Composites Science Technology, 62: 1357-1372.

[10] Lopez, JL, Sain M, Cooper P. (2006) Performance of natural-fiber-plastic composites under stress for outdoor applications: Effect of moisture, temperature, and ultraviolet light exposure. Journal Applied Polymer Science, 99: 2570-2577.

[11] Matuana LM, Jin S, Stark NM. (2011) Ultraviolet weathering of HDPE/wood flour composites coextruded with a clear HDPE cap layer. Polymer Degradation Stability, 96: 97106.

[12] Munajad A, Subroto C, Suwarno (2018). Fourier Transform Infrared (FTIR) Spectroscopy Analysis of Transformer Paper in Mineral Oil-Paper Composite Insulation under Accelerated Thermal Aging. Energies, 11(3), 364-378.

[13] Nur Aimi MN, Kamalbahrn MAM, Mohamed NS, Anuar H, Mel M, Othman R. (2011). Effect of Rhizopus oryzae fermentation on kenaf-based polylactic acid's monomer. IIUM Engineering Journal, 12: 83-87.

[14] Nur Aimi MN, Anuar H, Manshor MR, Wan Nazri WB, Sapuan SM. (2014) Optimizing the parameters in durian skin fiber reinforced polypropylene composites by response surface methodology. Industrial Crops Product, 54: 291-295.

[15] Nur Aimi MN, Anuar H, Maizirwan M, Sapuan SM, Wahit MU, Zakaria S. (2015). Preparation of Durian Skin Nanofibre (DSNF) and Its Effect on the Properties of Polylactic Acid (PLA) Biocomposites. Sains Malaysiana, 44: 1551-1559.

[16] Patpen, P, Rahman RA, Talib RA, Abdan K. (2015) Mechanical properties and water absorption behaviour of duriam rind cellulose reinforced poly (lactic acid) biocomposites. International Journal on Advanced Science Engineering Information Technology, 5: 343349. 
[17] Ramos M, Jiménez A, Peltzer M, Garrigós MC. (2014) Development of novel nanobiocomposite antioxidant films based on poly (lactic acid) and thymol for active packaging. Food Chemical, 1-31.

[18] Roncero ALT, Colom JF, Vidal T. (2005) The effect of xylanase on lignocellulosic components during bleaching of wood pulps. Bioresource Technology, 96: 21-30.

[19] Selvakumar V, Palanikumar K, Palanivelu K. (2010) Studies on mechanical characterization of polypropylene/Na+-MMT nanocomposites. Journal of Minerals and Materials Characterization and Engineering, 9: 671-681.

[20] Thwe MM, Liao K. (2002) Effects of environmental aging on the mechanical properties of bamboo-glass fiber reinforced polymer matrix hybrid composites. Composites: Part A, 33: 43-52.

[21] Yousif E, Haddad R. (2013) Review: Photodegradation and photostabilization of polymers, especially polystyrene. SpringerPlus, 2: 398. 